Artikel Penelitian

\title{
Gambaran Karakteristik Ibu, Penanganan Persalinan, dan Fetal Outcome pada Kehamilan Post-term
}

\author{
Anita Yulistiani ${ }^{1}$, Yanasta Moendanoe ${ }^{2}$, Yuniar Lestari ${ }^{3}$
}

\begin{abstract}
Abstrak
Kehamilan postterm berdampak besar pada janin dan juga ibu. Penyebab terjadinya belum jelas hanya ada beberapa faktor risiko, tetapi penyebab tersering adalah kesalahan penentuan usia kehamilan. Tujuan penelitian ini adalah untuk mengetahui karakteristik ibu, penanganan persalinan dan fetal outcome pada kehamilan post-term di RS M.Djamil periode 1 Januari 2010 samapai 31 Desember 2012. Jenis penelitian yang dilakukan adalah deskriptif dengan menggunakan data sekunder dari catatan rekam medis di bagian obstetri ginekologi RS M.Djamil pada 40 orang pasien yang mengalami kehamilan postterm. Hasil penelitian menunjukkan bahwa ibu yang mengalami kehamilan postterm terbanyak berada pada umur $20-35$ tahun $(92,5 \%)$ dengan paritas $0(47,5 \%)$, dan usia kehamilan 42-43 minggu (70\%). Terdapat pasien yang memiliki riwayat mentruasi tidak teratur (7,5\%), memiliki riwayat kontrasepsi hormonal 3 bulan terakhir (15\%) dan tidak ada yang memiliki riwayat USG trimester pertama. Hanya 2,5\% pasien yang memiliki riwayat postterm. Sebagian besar pasien memiliki skor bishop $<5(75 \%)$, hanya $6,67 \%$ yang dilakukan pematangan serviks. Teknik pematangan yang dilakukan sebanding antara farmakologis dan mekanis. Drip oksitosin diberikan pada $60 \%$ pasien, $83,33 \%$ diberikan saat skor bishop $<5$. Cara persalinan terbanyak menggunakan seksio sesarea $(52,5 \%)$. Sebanyak $50 \%$ pasien yang diberi drip, melahirkan secara pervaginam. Ditemukan bayi makrosomia $(7,5 \%)$. Jenis kelamin bayi menunjukan perbandingan yang sama antara laki-laki dan perempuan. Terdapat $7,5 \%$ kejadian stillbirth. Ditemukan bayi asfiksia berat $(2,7 \%)$ dan mild-moderate asphyxia $(21,62 \%)$. Sebanyak $7,5 \%$ bayi memiliki sindrom postmaturitas.
\end{abstract}

Kata kunci: post-term, karakteristik ibu, fetal outcome, penanganan persalinan

\begin{abstract}
Post-term pregnancy has a big impact on mother and fetus. The causes are still unclear, only several risk factors are known. However, the most frequent cause is dating error. The objective of this study was to find out the description of maternal characteristics, labor managemenet and fetal outcome in postterm pregnancy from period of $1^{\text {st }}$ Januari 2010 until 31 $1^{\text {st }}$ Desember 2012. The method of this research was descriptive that used secondary data from medical record of Obstetric dan Gynecology division in M.Djamil Hospital at 40 patient that have postterm pregnancy. The results showed mothers with post-term pregnancy were at the age of 20-35 (92,5\%) with parity of 0 (47,5\%) and the average of pregnancies were in 42-43 weeks (70\%). There were patients that had irregular menstrual cycle (7.5\%), last 3 months contraceptive history (15\%), and no one has first trimester USG. Only 2,5\% patients that have post-term pregnancy history. Mostly patients had bishop score $<5(75 \%)$ and only $6.67 \%$ experienced ripening of cervix. The technique of ripening was compared between mechanical and pharmacological. Oxytocin drip was given to $60 \%$ patients and $83.33 \%$ were given when bishop score $<5$. Most labor method used cesarean section of (52.5\%). Half of patients that were received a drip, delivering per vaginam. Macrosomia babies are found (7.5\%). Babies gender show equal comparison between male and female. There were $7.5 \%$ stillbirth cases. Severe asphyxia was found (2.7\%) and mild-moderate asphyxia (21.62\%). There were $7.5 \%$ babies that have postmaturity syndrome.The LMP formula to calculate gestasional age at M. Djamil Hospital seems inaccurate
\end{abstract}

Keywords: post-term, maternal characteristics, fetal outcome, labor management 
Affiliasi penulis: 1. Prodi Profesi Dokter FK Unand (Faklutas Kedokteran Universitas Andalas Padang), 2. Bagian Obstetrik dan Ginekologi FK Unand, 3. Bagian IImu Kesehatan Masyarakat FK Unand

Korespondensi: Anita Yulistiani, Email :

anitayulistiani92@gmail.com, Telp: 085374715004

\section{PENDAHULUAN}

Kehamilan umumnya berlangsung 40 minggu atau 280 hari. Sedangkan kehamilan aterm ialah usia kehamilan antara 38-42 minggu dan ini merupakan periode terjadinya persalinan normal. ${ }^{1}$ Kehamilan postterm adalah kehamilan yang telah mencapai usia 42 minggu atau lebih dari usia gestasi (294 hari atau lebih dari 14 hari tanggal taksiran persalinan). ${ }^{2}$

Pengaruh kehamilan postterm terutama adalah terhadap janin. Meskipun hal ini masih banyak diperdebatkan dan belum ada kesesuaian paham, dalam kenyataannya kehamilan postterm memang memberi pengaruh terhadap perkembangan janin sampai pada kematian janin. ${ }^{3}$ Pada kehamilan post-term juga dapat terjadi pertambahan berat janin dalam rahim dan ini meningkatkan risiko persalinan yang berat. ${ }^{1}$

Penyebab kehamilan postterm sampai saat ini belum jelas, beberapa teori yang diajukan umumnya menyatakan bahwa terjadinya kehamilan postterm sebagai akibat gangguan terhadap timbulnya persalinan seperti pengaruh progesteron, oksitosin dan lain-lain. ${ }^{1}$ Ada beberapa faktor yang bisa menempatkan seorang wanita menjadi golongan berisiko tinggi seperti primipara, riwayat kehamilan post-term sebelumnya, dan jenis kelamin bayi laki-laki. ${ }^{4}$ Kehamilan post-term ini sering ditemukan pada kelompok usia 20-35 tahun. ${ }^{5}$ Tetapi hal tersering penyebab diagnosis kehamilan postterm adalah kesalahan dalam penanggalan. Penggunaan perhitungan HPHT sebagai penentu usia kehamilan sering tidak akurat. Pasien yang lupa tanggal HPHT ditambah lagi dengan variasi fase luteal dan follicular dari siklus menstruasi berakibat pada kesalahan yang dapat berupa bertambahnya usia kehamilan. ${ }^{6}$ Bagi wanita yang tidak memenuhi persyaratan-persyaratan tersebut, USG pada awal kehamilan terutama pada trimester pertama adalah pilihan terbaik untuk penentuan usia gestasi . $^{4}$

Pengelolaan kehamilan post-term sampai saat ini masih menjadi kontroversi, apakah sebaiknya segera dilakukan induksi setelah ditegakan diagnosis post-term atau sebaiknya dilakukan pengelolaan secara ekspektatif atau menunggu sampai persalinan berlangsung sendirinya sambil terus menerus dilakukan pengawasan terhadap janin. Pada kenyataannya saat kehamilan mencapai 42 minggu, pada beberapa penderita didapatkan sekitar $70 \%$ serviks belum matang. Hal ini yang menyebabkan induksi persalinan tidak selalu berhasil, sedangkan persalinan yang berlarut-larut akan sangat merugikan bayi postmatur. ${ }^{1}$

RS Dr. M. Djamil Padang dipilih sebagai lokasi penelitian karena merupakan pusat rujukan bagi instansi kesehatan lainnya.

\section{METODE}

Jenis penelitian yang akan dilakukan adalah penelitian deksriptif dengan menggunakan data sekunder yang diperoleh dari catatan rekam medis kasus persalinan post-term di bagian obstetri dan ginekologi RS M.Djamil periode 1 Januari 2010 - 31 Desember 2012. Populasi penelitian adalah seluruh kasus persalinan dengan kehamilan postterm di bagian Obstetri dan Ginekologi RS M.Djamil Padang periode 1 Januari 2010 - 31 Desember 2012. Sampel dalam penelitian ini adalah seluruh anggota populasi yang memenuhi kriteria inklusi yaitu kehamilan tunggal. Kriteria eksklusi adalah data pada rekam medik tidak lengkap. Pengolahan data dilakukan secara manual dan hasil disajikan dalam bentuk tabel dan narasi. Hasil dianalisis dengan analisis deskriptif.

\section{HASIL}

Penelitian yang telah dilakukan di RS M.Djamil Padang selama periode 1 Januari 2010 31 Desember 2012 mendapatkan 75 kasus persalinan postterm. Dari 75 kasus tersebut, didapatkan 40 kasus yang memiliki data sesuai dengan kriteria inklusi. Selanjutnya 40 kasus post- 
term tersebut dijadikan sebagai subjek penelitian.

Berikut adalah hasil yang diperoleh :

Tabel 1. Gambaran karakteristik ibu

\begin{tabular}{lcc}
\hline Karakteristik Ibu & Jumlah & Persentase(\%) \\
\hline Umur & & \\
20 tahun & 0 & 0 \\
$20-35$ tahun & 37 & 92,5 \\
$>35$ tahun & 3 & 7,5 \\
\hline Paritas & 19 & \\
0 & 9 & 47,5 \\
1 & 12 & 22,5 \\
$>1$ & & 30 \\
\hline Usia Kehamilan & \\
42-43 minggu & 28 & 70 \\
$\quad>43$ minggu & 12 & 30 \\
\hline Riwayat Menstruasi & & \\
Teratur & 37 & 92,5 \\
Tidak Teratur & 3 & 7,5 \\
\hline Riwayat Kontrasepsi & & \\
Ada & 6 & 15 \\
Tidak Ada & 34 & 85 \\
\hline Riwayat USG Trimester Pertama & & \\
Ada & 0 & 0 \\
Tidak Ada & 40 & 100 \\
\hline Riwayat Persalinan Postterm & & \\
Ada & 1 & 2,5 \\
Tidak Ada : & & \\
$\quad$ Sudah pernah melahirkan & 20 & 50 \\
Belum pernah melahirkan & 19 & 47,5 \\
\hline
\end{tabular}

Tabel 1 memperlihatkan bahwa umur pasien yang mengalami kehamilan post-term terbanyak adalah pada usia 20-35 tahun yaitu sebanyak 37 orang $(92,5 \%)$. Naz et al juga mendapatkan hal yang serupa yaitu kelompok usia terbanyak dari ibu yang mengalami kehamilan postterm di RS Jinnah Lahore adalah pada usia 20-35 sebanyak $86,7 \%{ }^{5}$ Hal ini bisa dipahami karena puncak kesuburan seorang wanita berada pada rentang usia ini dengan memiliki peluang mencapai 95\% untuk dapat terjadinya kehamilan. ${ }^{7}$ Sehingga sebagian besar persalinan memang berlangsung pada rentang usia tersebut.

Tabel 2. Gambaran skor Bishop

\begin{tabular}{ccc}
\hline Skor Bishop & Jumlah & Persentase (\%) \\
\hline$<5$ & 30 & 75 \\
$\geq 5$ & 10 & 25 \\
\hline Jumlah & 40 & 100 \\
\hline
\end{tabular}

Tabel 2 memperlihatkan sebagian besar pasien yang mengalami kehamilan postterm memiliki skor bishop kurang dari 5 yaitu sebanyak 30 orang $(75 \%)$. Hal ini serupa dengan penelitian yang dilakukan oleh Alash et al yang mendapatkan lebih dari $70 \%$ wanita yang telah mencapai usia kehamilan 42 minggu memiliki skor bishop $<5 .{ }^{12}$

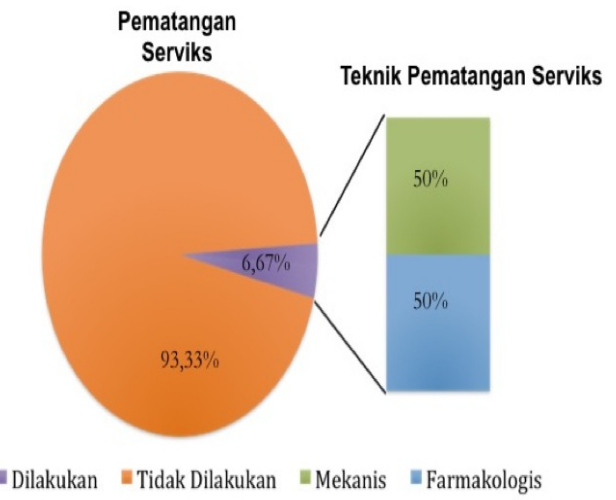

Gambar 1. Gambaran pematangan serviks dan teknik pematangan serviks

Gambar 1 memperlihatkan 30 orang pasien yang memiliki skor bishop $<5$, hanya sebanyak 2 orang $(6,67 \%)$ yang dilakukan pematangan serviks. Dari 2 orang pasien yang dilakukan pematangan seviks tersebut, teknik pematangan dilakukan sebanding antara farmakologis dan mekanis

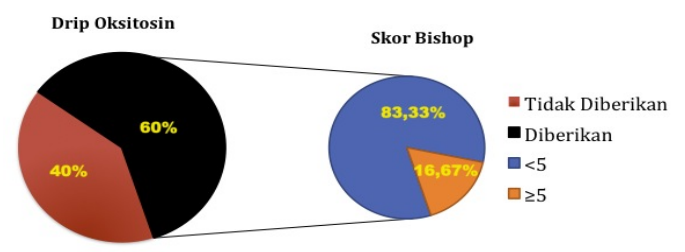

Gambar 2. Gambaran pemberian drip oksitosin dan kondisi skor bishop

Gambar 2 memperlihatkan dari 40 pasien, lebih dari separuhnya menerima drip oksitosin, yaitu sebanyak 24 orang $(60 \%)$. Kemudian dari 24 orang yang menerima drip oksitosin tersebut, hampir seluruhnya yaitu sebanyak 20 orang (83,33\%) diberikan drip pada saat skor bishop pasien kurang dari 5.

Tabel 3. Cara persalinan

\begin{tabular}{ccc}
\hline Jenis Persalinan & Jumlah & Persentase (\%) \\
\hline Pervaginam & 19 & 47,5 \\
Seksio Sesarea & 21 & 52,5 \\
\hline Jumlah & 40 & 100 \\
\hline
\end{tabular}


Tabel 3 memperlihatkan bahwa cara persalinan terbanyak yang dilakukan pada kehamilan posterm adalah dengan cara seksio sesarea yaitu sebanyak 21 orang $(52,5 \%)$.

Tabel 4. Drip oksitosin dan cara persalinan

\begin{tabular}{cccccc}
\hline \multicolumn{4}{c}{ Drip $(+)$} & \multicolumn{2}{c}{ Drip $(-)$} \\
\hline Cara Persalinan & Frekuensi & $(\%)$ & Frekuensi & $(\%)$ & Jumlah \\
\hline Pervaginam & 12 & 50 & 7 & 43,75 & 19 \\
Seksio Sesarea & 12 & 50 & 9 & 56,25 & 21 \\
\hline Jumlah & 24 & 100 & 16 & 100 & 40 \\
\hline
\end{tabular}

Tabel 4 memperlihatkan hanya sebanyak 12 orang $(50 \%)$ pasien yang diberikan drip oksitosin mampu melahirkan secara pervaginam.

Hasil ini berbeda dengan yang dipaparkan oleh Ekele et al melalui penelitiannya selama 2 tahun yang dilakukan di RS Usmanu Danfodiyo, Nigeria. Rumah sakit ini menggunakan prosedur pematangan serviks terlebih dahulu secara farmakologis sebelum diberikan drip oksitosin dan ternyata keberhasilan berlangsungnya persalinan secara pervaginam mencapai 96\%, sedangkan sebelumnya rumah sakit ini menggunakan metode pematangan serviks secara mekanis dan hanya mencapai keberhasilan sebesar $82 \%{ }^{14}$

Tabel 5. Gambaran fetal outcome

\begin{tabular}{|c|c|c|}
\hline Fetal Outcome & Jumlah & Persentase $\%$ \\
\hline \multicolumn{3}{|l|}{ Berat Badan Lahir } \\
\hline$<2500$ gram & 0 & 0 \\
\hline $2500-4000$ gram & 37 & 92,5 \\
\hline >4000 gram & 3 & 7,5 \\
\hline \multicolumn{3}{|l|}{ Jenis Kelamin } \\
\hline Perempuan & 20 & 50 \\
\hline Laki-laki & 20 & 50 \\
\hline \multicolumn{3}{|l|}{ Stillbirth } \\
\hline Ada & 3 & 7,5 \\
\hline Tidak Ada & 37 & 92,5 \\
\hline \multicolumn{3}{|l|}{ Apgar Score } \\
\hline $0-3$ & 1 & 2,7 \\
\hline $4-6$ & 8 & 21,62 \\
\hline $7-10$ & 28 & 75,68 \\
\hline \multicolumn{3}{|c|}{ Sindrom Postmaturitas } \\
\hline Ada & 3 & 7,5 \\
\hline Tidak Ada & 37 & 92,5 \\
\hline
\end{tabular}

Tabel 5 memperlihatkan terdapat 3 orang (7,5\%) bayi lahir dengan berat lebih dari 4000 gram. Hal ini sesuai dengan yang dikatakan oleh Foyouzi dan Norwitz bahwa pada kehamilan postterm, kejadian bayi makrosomia dapat berkisar antara 2,5-10\%. ${ }^{16}$ Menurut teori, dalam kehamilan postterm berat badan janin dapat meningkat, tidak bertambah, maupun janin dapat lahir dengan berat badan kurang dari normal. Hal ini tergantung dari fungsi plasenta. ${ }^{3}$ Keadaan yang terjadi di RS M.Djamil menunjukkan keadaan fungsi plasenta yang mungkin masih cukup baik sehingga janin masih dapat mengalami pertumbuhan dan memiliki berat badan seperti itu.

Terlihat juga perbandingan yang sama antara jenis kelamin bayi laki-laki dan perempuan. Hal ini sedikit berbeda dengan yang didapatkan oleh Naz F, bahwa sebesar $66,7 \%$ bayi dari kehamilan postterm adalah laki-laki. ${ }^{5}$ Laczna et al, juga mengatakan bahwa ratio perbandingan jenis kelamin antara bayi laki-laki dan perempuan pada kehamilan postterm adalah 1,3:1. ${ }^{17} \mathrm{Hal}$ ini mungkin diakibatkan karena adanya faktor genetik berupa kelainan gen $x$-linked recessive defisiensi sulfatase plasenta yang membawa hal ini kepada abnormalitas produksi estrogen pada janin laki-laki yang terkena dengan berakibat pada pemanjangan waktu kehamilan, kesulitan dalam pematangan serviks dan induksi persalinan secara berturutturut. ${ }^{13}$ Selain itu, hal ini juga bisa dikarenakan adanya perbedaan dari penghitungan antopometri tubuh antara kedua jenis kelamin bayi ini, yang membuat bayi laki-laki lebih sering terdiagnosa pada kejadian kehamilan postterm. ${ }^{17}$ Di RS M.Djamil hal ini tidak terjadi, ini mungkin dikarenakan tidak terjadinya kelainan genetik pada bayi-bayi dari kehamilan postterm tersebut dan juga bisa disebabkan karena tidak dihitungnya antopometri kedua jenis kelamin bayi tersebut pada penelitian ini.

\section{PEMBAHASAN}

Pada karakteristik pasien terlihat paritas yang terbanyak adalah pada paritas 0 yaitu sebanyak 19 orang (47,5\%). Hal ini serupa dengan 
penelitian yang dilakukan Roos et al, bahwa sebanyak $51,4 \%$ kehamilan postterm berada pada paritas 0 . la juga mengatakan bahwa nullipara adalah salah satu faktor risiko untuk terjadinya kehamilan postterm. la menduga hal ini dikarenakan pada nullipara jumlah gap junction pada miometriumnya tidak sebanyak wanita yang sudah pernah mengalami persalinan sebelumnya. ${ }^{8} \mathrm{Hal}$ ini berbeda dengan yang didapatkan oleh Weerawetwat et al, dalam penelitiannya ia mendapatkan jumlah primipara yang lebih banyak mengalami kehamilan post-term yaitu sebanyak $59,8 \% .^{9}$ Sampai saat ini belum ada literatur yang dapat menjelaskan mengenai kedua perbedaan tersebut.

Usia kehamilan post-term terbanyak adalah pada usia kehamilan 42-43 minggu sebanyak 28 orang $(70 \%)$ dan hanya 11 orang atau $30 \%$ yang berlanjut melebihi 43 minggu. Penurunan jumlah seiring bertambahnya usia kehamilan ini sejalan dengan penelitian yang dilakukan oleh Heimstad berdasakan catatan kelahiran di Norwegia tahun 2002 bahwa hanya 2,7\% persalinan yang melebihi usia kehamilan 43 minggu dari seluruh persalinan, sedangkan pada usia kehamilan 42-43 minggu mencapai $8,7 \% .^{10}$ Hal ini diperkirakan karena cepatnya penanganan di RS M.Djamil yang diberikan segera setelah diketahui kehamilan tersebut adalah kehamilan postterm sehingga ibu yang berlanjut usia kehamilannya melebihi 43 minggu tidak terlalu banyak.

Sebanyak 3 orang $(7,5 \%)$ memiliki riwayat menstruasi yang tidak teratur. Sebanyak 6 orang (15\%) memiliki riwayat kontrasepsi sebelumnya. Seluruh pasien tidak memiliki riwayat USG trimester pertama. Hal ini menunjukkan kurang akuratnya diagnosis postterm di RS M.Djamil karena seharusnya diagnosis usia kehamilan berdasarkan HPHT hanya bisa mencapai akurasi yang tinggi dengan syarat menstruasi teratur dan tidak ada riwayat pemakaian kontrasepsi hormonal selama 3 bulan terakhir. ${ }^{1}$ Sebaiknya pada wanita dengan kondisi ini diagnosis kehamilan postterm dilakukan menggunakan USG di awal kehamilan terutama pada trimester pertama yang memiliki akurasi tinggi dalam penentuan usia gestasi. ${ }^{4}$ Namun, dari semua responden tidak ada satupun yang melakukan USG trimester pertama tersebut. Hal ini memperlihatkan adanya kemungkinan kesalahan diagnosis dari kehamilan postterm yang ada di RS M.Djamil.

Hanya 1 orang ibu (2,5\%) yang memiliki riwayat kehamilan postterm sebelumnya Sedangkan pada penelitian yang dilakukan oleh Olesen melalui studi kohort di Denmark, didapatkan bahwa sebesar 19,9\% kehamilan postterm dapat terjadi rekurensi. Rekurensi ini dapat menurun menjadi $15,4 \%$ apabila anak pertama dan anak kedua memiliki ayah yang berbeda. Oleh karena itu ia menduga adanya peran gen dari ayah berpengaruh terhadap lamanya kehamilan ini. ${ }^{11}$ Mungkin di Padang khususnya di RS M.Djamil, peran genetik ini tidak terlalu berpengaruh, sehingga angka ibu yang memliki riwayat kehamilan postterm tidak terlalu besar. Hal ini juga mungkin disebabkan karena perbedaan jenis penelitian yang dilakukan, sehingga hasil yang didapatkan juga berbeda.

Pasien yang mengalami kehamilan postterm memiliki skor bishop kurang dari 5 yaitu sebanyak 30 orang (75\%). Proses pematangan serviks dapat dipengaruhi hormon lain seperti estrogen yang dapat menstimulasi aktifitas degradasi yaitu degradasi dari kolagen serviks dan progesteron bersifat kebailkannya yaitu memblokade aktifitas tersebut. Sehingga tingginya kadar progesteron pada wanita ataupun kurangnya kadar estrogen seperti pada kelainan gen $x$-linked recessive defisiensi sulfatase plasenta, pematangan serviks menjadi terhambat untuk terjadi. ${ }^{13}$ Di RS M.Djamil hal ini mungkin terjadi karena adanya kesalahan penghitungan usia kehamilan, sehingga kadar progesteron ibu tersebut masih tinggi dan mengakibatkan belum matangnya serviks.

Di RS M.Djamil sebagian besar ibu juga melahirkan dengan cara seksio sesarea yaitu sebanyak 21 orang (52,5\%) dengan indikasi terbanyak adalah gagal drip. Hal ini berbeda dengan penelitian yang dilakukan oleh Weerawatwat et al yang mendapatkan persalinan dengan seksio sesarea pada kasus kehamilan postterm hanya terjadi pada $23,7 \%$ pasien. $^{9}$ Menurut teori, drip oksitosin akan lebih efektif 
menstimulasi kontraksi uterus apabila serviks telah matang $^{15}$. Oleh sebab itu, mungkin rendahnya angka persalinan pervaginam pada ibu yang telah diberikan drip oksitosin dan tingginya insiden seksio sesarea pada kehamilan postterm di RS M.Djamil dikarenakan kurang diberlakukannya prosedur pematangan serviks.

Hasil penelitian ini juga menemukan adanya bayi yang mengalami stillbirth yaitu sebanyak 3 orang $(7,5 \%)$. Semuanya adalah pasien rujukan yang telah mengalami IUFD. Dua ibu diantaranya memiliki penyakit penyerta seperti PEB dan hipertensi gestasional. Salah satunya telah memasuki usia kehamilan 44-45 minggu. Satu orang lagi mengalami partus yang tidak maju selama penanganan di daerah dan saat sampai di RS M.Djamil, sisa ketuban ibu sudah berwarna kehijauan. Namun dari status, dikatakan bahwa sang ibu sudah merasakan hilangnya gerak janin sejak 5 jam sebelum ia ke RS daerah. Hal ini cukup berbeda dengan penelitian lain dilakukan oleh Ingemarsson dan Kallen yang hanya mendapatkan 2,26\% kejadian stillbirth pada kehamilan postterm di Swedia. ${ }^{18}$ Tingginya angka kejadian stillbirth, menunjukkan besarnya akibat dari kehamilan postterm ini, hal ini diperburuk dengan penyakit penyerta yang diderita oleh ibu. Selain itu seiring dengan peningkatan usia kehamilan, area yang mengalami infark juga bertambah luas sehingga berefek pada kemampuan oksigenasinya kepada fetus, sehingga memungkinkan untuk terjadi hipoksia janin. ${ }^{19}$ Hal-hal tersebutlah yang mungkin berkaitan dengan kejadian stillbirth di RS M.Djamil. Namun, hal ini terjadi bukan karena buruknya penanganan di RS M.Djamil, karena semua pasien datang sudah dalam keadaan janin yang mengalami IUFD.

Dari 37 orang bayi lahir hidup, terdapat $2,7 \%$ bayi mendertita asfiksia berat dan $21,62 \%$ bayi menderita mild-moderate asphyxia. Penelitian lain yang dilakukan Weerawetwat et al memiliki hasil yang berbeda, ia hanya mendapatkan $3,75 \%$ bayi yang menderita mild-moderate asphyxia dan 1,25\% bayi asfiksia berat. ${ }^{9}$ Asfiksia neonatorum dapat merupakan kelanjutan dari kegawatan janin (fetal distress). Fetal distress adalah keadaan ketidakseimbangan antara kebutuhan $\mathrm{O}_{2}$ dan nutrisi janin, atau sering juga diartikan sebagai janin yang mengalami hipoksia. $^{20}$ Cukup tingginya angka kejadian asfiksia di RS M.Djamil ini menunjukkan besarnya akibat dari kehamilan postterm yang terjadi. Selain itu beberapa diantaranya juga adalah bayi-bayi yang mengalami anencephal. Namun hal ini bukanlah dikarenakan penanganan di RS M.Djamil yang kurang baik, tetapi memang karena sebagian besar sang ibu yang memiliki bayi asfiksia ini, saat pertama kali datang di RS M.Djamil dan segera dilakukan pemeriksaan, ternyata janinnya sudah mengalami fetal distress. Beberapa diantaranya adalah kirimian dari RS daerah yang memiliki keterbatasan alat dan tenaga ahli, serta jarak tempuh yang cukup jauh kemungkinan mempengaruhi juga akan kejadian ini.

Hanya ada 3 orang $(7,5 \%)$ bayi yang lahir dengan memiliki sindrom postmaturitas. Dari literatur dikatakan bahwa tidak semua bayi postterm mengalami sindrom postmaturitas. Caughey mengatakan hanya sekitar $20 \%$ bayi dari kehamilan postterm mengalami sindrom postmaturitas. Hal ini tergantung pada fungsi plasenta. Infark pada plasenta dan menuanya usia plasenta dikaitkan dengan ini. ${ }^{4}$ Kemungkinan, kecilnya angka kejadian sindrom postmaturitas di RS M.Djamil mungkin dikarenakan penurunan fungsi plasenta belum terlalu besar terjadi. Selain itu hal ini bisa juga disebabkan karena kesalahan diagnosa kehamilan tersebut yang sebenarnya bukan kehamilan posttterm tapi terdiagnosa sebagai postterm, akibat lemahnya akurasi diagnosa yang dilakukan di RS M.Djamil melalui penggunaan HPHT yang tidak memenuhi syarat.

\section{SIMPULAN}

Karaketristik ibu pada kehamilan postterm terbanyak berada pada umur 20-35 tahun (92,5\%) dengan paritas $0(47,5 \%)$, dan rata-rata kehamilan berusia $42-43$ minggu (70\%). Terdapat pasien yang memiliki riwayat mentruasi tidak teratur $(7,5 \%)$, memiliki riwayat kontrasepsi hormonal 3 bulan terakhir (15\%) dan tidak ada yang memiliki riwayat 
USG trimester pertama. Hanya sedikit pasien yang memiliki riwayat kehamilan postterm sebelumnya $(2,5 \%)$. Sebagian besar pasien memiliki skor bishop $<5(75 \%)$ dan hanya $6,67 \%$ yang dilakukan pematangan serviks. Teknik pematangan yang dilakukan sebanding antara farmakologis dan mekanis. Drip oksitosin diberikan pada 60\% pasien. Cara persalinan terbanyak adalah dengan menggunakan seksio sesarea $(52,5 \%)$

Angka kejadian penanganan persalinan postterm yang diberi drip oksitosin pada saaat skor bishop $<5$ adalah sebesar 83,33\%. Angka kejadian penanganan persalinan post-term yang diberi drip oksitosin dan melahirkan dengan cara pervaginam adalah sebanyak $50 \%$. Karakteristik fetal outcome menunjukkan adanya bayi makrosomia (7,5\%). Jenis kelamin bayi menunjukan perbandingan yang sama antara laki-laki dan perempuan. Terdapat 7,5\% kejadian stillbirth. Asfiksia berat ditemukan pada $2,7 \%$ bayi dan $21,62 \%$ menderita mildmoderate asphyxia. Hanya sebagian kecil bayi yang memiliki sindrom postmaturitas $(7,5 \%)$.

\section{UCAPAN TERIMA KASIH}

Terima kasih kepada semua pihak yang telah banyak mengorbankan waktu, pikiran dan tenaga dalam memberikan arahan dan masukan dalam penelitian ini.

\section{DAFTAR PUSTAKA}

1. Mochtar $A B$, Kristanto $H$. Kehamilan postterm. Dalam: Wiknjosastro $\mathrm{H}$, Rachimhadhi $\mathrm{T}$, editor (penyunting). IImu kebidanan Sarwono Prawirohardjo. Edisi ke-4. Jakarta: PT Bina Pustaka; 2010. hlm.685-95.

2. ACOG. Management of postterm pregnancy. ACOG Practice Bulletin. 2004;104(3):639-46.

3. Mochtar $A B$, Kristanto $H$. Kehamilan Lewat Bulan. Dalam: Hariadi R, editor (penyunting). IImu kedokteran fetomaternal. Edisi ke-1. Surabaya : Himpunan Kedokteran Fetomaternal Perkumpulan Obstetri dan Ginekologi Indonesia; 2004
4. Caughey AB. Postterm pregnancy. [serial online] 2011 (diunduh 15 April 2013). Tersedia dari URL: HYPERLINK http://emedicine. medscape.com/article/261369-overview

5. Naz F, et al. Neonatal outcome in post-term pregnancy. [serial online] 2009 (diunduh 2 Februari 2014). Tersedia dari: URL: HYPERLINK http://pjmhsonline.com/neonatal outcome in post.htm.

6. Collins E. Postdates pregnancy : what is it and what to do with it? definition and management. Dalam: Roberts CP, Broomfield DP, editor (penyunting). Avoiding common obstetrics and gynecology errors. Philadelphia: Lippincott Williams \& Walkins; 2011.hlm.63 - 4.

7. Anggarani DR, Dubakti Y. Persiapan kehamilan. Dalam Hamzah I, editor (penyunting). Kupas tuntas seputar kehamilan. Edisi ke-1, Jakarta :Agromedia Pustaka; 2013.hlm.3.

8. Roos $\mathrm{N}$, et al. Maternal risk factors for postterm pregnancy and cesarean delivery following labor induction. Acta Obstetricia et Gynecologica. 2010;(89):1003-10.

9. Weerawetwat $\mathrm{W}$, et al. Postterm pregnancy: induction of labor vs conservative mangement. Thai Journal of Obstetrics and Gynaecology. 2000;12:109-16.

10. Heimstad R. Postterm pregnancy (tesis). Trondheim: Norwegian University of Science and Technology; 2007.

11. Olesen AW. Risk of recurrence of prolonged pregnancy. BMJ. 2003;326:476.

12. Alash AM, Barqawi RA, Irshid IHB. Management of post-date pregnancies with unfavorable cervix in primigravida. JRMS. 2006;13(1):19-22.

13. Andersson S. Estrogen and progesterone metabolism in the cervix during pregnancy and parturition. J Clin Endocrinol Metab. 2008; 93(6): 2366-74.

14. Ekele BA, et al. Misoprostol use for ripening and induction labour in Nigerian teaching hospital. Nigerian Journal of Clinical Practice. 2007; 10(3):234-37. 
15. Resnik JL, Resnik R. Post-term pregnancy. Dalam: Creasy RK, Resnik R, Lams JD, editor (penyunting). Maternal - fetal medicine. Edisi ke-6. Philadelphia: Saunders Elsevier; 2009. hlm 613-17.

16. Foyouzi N, Norwitz ER. Postterm pregnancy. Dalam: Funai E, Evans M, Lockwood C, editor (penyunting). High risk obstetrics: The requisites in obstetrics and gynecology. Edisi ke-1. Philadelphia : Mosby Elsevier;2008.hlm.205- 11.

17. Laczna MK, et al. Skewed fetal gender distribution in prolonged pregnancy: a fallacy with consequences. Ultrasound Obstet Gynecol. 2003;21:262-6.
18. Ingemarsson I, Källén K. Stillbirths and rate of neonatal deaths in 76,761 postterm pregnancies in Sweden, 1982-1991: a register study. Acta Obstet Gynecol Scand.1997;76(7):658-62.

19. Cashion K. Labor and birth complications. Dalam: Herdman TH, editor (penyunting). Maternal child nursing care. Edisi ke-5. Missouri: Elseiver Mosby; 2012. hlm.453.

20. Manuaba IBG. Kegawatdaruratan pada neonatus. Dalam: Astuti NZ, Purba DL, Handayani S, Damayani R, editor (penyunting) Pengantar kuliah obstetri. Jakarta: EGC;2007. hlm.841-2. 